\title{
THE YIELDING CAPACITY \\ OF TETRAPLOID SUGAR AND FODDER BEETS
}

\author{
MET SAMENVATTING \\ HET OPBRENGSTVERMOGEN \\ VAN TETRAPLOIDE SUIKER- EN VOEDERBIETEN
}

D. KLOEN and G. J. SPECKMANN

\author{
MEDEDELING No. 22 \\ VAN DE \\ STICHTING VOOR PLANTENVEREDELING
}

OVERDRUK UIT EUPHYTICA 8 (1959): 29-36 


\section{STICHTING VOOR PLANTENVEREDELING, S.V.P. NUDE 66, WAGENINGEN}

Ir. J. I. C. ButLeR,

BESTUUR te Wageningen

- voorzitter, als lid rechtstreeks benoemd door de Minister

Dr. Ir. J. P. DudoK van HeEl, - vice-voorzitter, benoemd op voordracht van de Nete Naarden

Prof. Ir. M. L 't HaRT, te Wageningen derlandse Kwekersbond

- secretaris, benoemd op voordracht van de Senaat van de Landbouwhogeschool

Ir. D. J. v. D. HAvE, te Kapelle-Biezelinge

- lid, benoemd op voordracht van de Nederlandse Kwekersbond

Ir. J. W. LACKAMP, te Ottersum

Ir. G. W. MEYER, te Leeuwarden

- lid, benoemd op voordracht van de Nederlandse Kwekersbond en Landbouwschap samen

- lid, benoemd op voordracht van de Nederlandse Algemene Keuringsdienst

A. VISSER, te Dordrecht

Prof. Dr. Ir. J. C. DoRst, te Wageningen

Ir. P. A. DEN ENGELSE, te 's-Gravenhage

- lid, benoemd op voordracht van het Landbouwschap

- adv. lid, benoemd op voordracht van het Bestuur van de S.V.P.

- adv. lid, benoemd op voordracht van het Bestuur van de S.V.P.

\section{STAF}

Dr. Ir. F. E. NIJDAM

- Directeur

Dr. Ir. H. LAMBERTS

- Adjunct-Directeur

Dr. Ir. C. A. HuIJSMAN

Ir. G. A. THuN

Ir. H. T. WIERSEMA

Dr. F. WIT

Ir. G. E. vaN DIJK

Ir. J. DiJKSTRA

Ir. G. CleIJ

Ir. D. KLOEN

Dr. Ir. G. Dantuma

Ir. J. MesDaG

Dr. Ir. H. LAMBERTS

Ir. K. Hoen Ph. D.

Ir. H. T. WIERSEMA

G. J. SPECKMANN

A. J. Glerum

J. HoLmaN

M. H. AgeLINK

Aardappelveredeling

Grassen- en Klaververedeling

Voeder-en Suikerbietenveredeling

Tarwe-, gerst- en haververedeling

Zoete lupinen-, stoppelknollen-, wikken-, serradella-, landbouwstambonen-, en erwtenveredeling

- Vlas- en koolzaadveredeling

- Cytologie

- Bedrijfsleider Proefboerderij Prof. Broekemahoeve, Marknesse (N.O.P.)

- Bedrijfsleider te Wageningen

- Hoofd Algemene Zaken 


\title{
THE YIELDING CAPACITY OF TETRAPLOID SUGAR AND FODDER BEETS
}

\author{
D. KLOEN and G. J.SPECKMANN \\ Foundation for Agricultural Plant Breeding, Wageningen \\ With 4 figures \\ Received 6 July 1958
}

\begin{abstract}
Since the discovery of the use of colchicine in plant breeding, breeders have created tetraploid sugar and fodder beet. The results obtained were not very encouraging and therefore they soon proceeded to develop varieties containing triploids.

At the Foundation for Agricultural Plant Breeding, Wageningen, polyploidy breeding was started in 1950. The initial material comprised two sugar beet varieties and five fodder beet varieties. By cytological examination of the aberrant individuals in the first and the second year after colchicine treatment, seed was obtained which produced a high percentage of tetraploids. In total $793 \mathrm{C}_{2}$ families were tested on trial fields and from these $32 \%$ appeared to be better than the original diploid material.

The breeders interested in the material were provided with seed and stecklings of all the families in the $\mathrm{C}_{1}, \mathrm{C}_{2}$ or $\mathrm{C}_{3}$ stage. With the distribution of this material the building up of tetraploid families at the Foundation for Agricultural Plant Breeding has been closed.
\end{abstract}

\section{INTRODUCTION}

In 1938 it was discovered that colchicine influences cell division in such a way that no new cell-wall is produced, thus resulting in a cell with a double number of chromosomes. Beet research workers have soon utilized colchicine in the creation of tetraploid beets.

In the U.S.A. and Canada the first results were recorded in 1940 by ABEGG (1) and Peto \& Boyes (8). In a one-year trial Amstrong (3) was not optimistic about the yielding capacity, but ABEGG (2) stated in 1946 that some tetraploid families made a favourable impression. PETo and HILL (9) also obtained good results with their tetraploid sugar beets, although good types were few and far between. In 1952 similar results were published by STEWART and GASKILL (13). This is the reason why polyploidy breeding in these countries has not been adopted on a large scale.

In Western Europe similar results were obtained by SCHLösSER (12), FrandSEN (5) and ERnould (4). The only advantages mentioned were a better leaf-development, a lesser tendency to bolting, a better shape of fodder-sugar beet and fodder beet and a lesser tendency to produce fanged beets.

Thus, tetraploid beet have not yielded the results which had been expected. May be the initial material was not comprehensive enough, and limited the possibilities of obtaining better types. In addition it soon appeared that triploids offered better prospects and the tetraploid families were used only for crossing, in order to produce 
triploids. However, the successes achieved with tetraploids in Japan have induced research workers in the U.S.A. and Canada to pay more attention to this work.

The Foundation for Agricultural Plant Breeding, Wageningen, started with polyploidy breeding in 1950 . The aim was to create tetraploids from a number of diploid commercial varieties and to use the new material for intercrossing and the production of triploids. It was assumed that by using varieties of a quite different type heterosis would occur and that this would open new opportunities for the breeding work in general. Prospective crosses would be most effective when a start was made with valuable tetraploid material.

In recent years this procedure has been carried out with all the tetraploid families obtained in 1951, 1952 and 1953. Beet breeders have received seed and stecklings of these families in order to broaden their selection basis.

In this publication a report will be given of the way in which the tetrapioid material can be compared with the initial diploid material.

\section{THE COURSE OF THE INVESTIGATION}

\section{$C_{0}$ generation}

The Foundation for Agricultural Plant Breeding has no beet varieties of its own. Therefore commercial seed of 7 diploid varieties was treated with colchicine in 1950 , 1951 and 1953 (KLOEN and SpeckmanN, 6). In total 32,500 clusters were used and after the treatment 3,146 aberrant individuals were planted in the field. After cytological examination it was possible to store 780 "tetraploids" in a pit. In the second year they were all planted and again examined cytologically before flowering. The nontetraploids were rejected.

The following table gives the number of $\mathrm{C}_{0}$ beets of which seed was harvested.

TABle 1. Number of $C_{0}$ BeEts OF WHich SEed WAS haRvested

\begin{tabular}{|c|c|c|c|}
\hline Group & $\begin{array}{l}\text { Commercial } \\
\text { varieties }\end{array}$ & $\begin{array}{c}\text { Tetraploid } \\
\text { varieties }\end{array}$ & $\begin{array}{l}\text { Number of seed } \\
\text { bearing } C_{0} \text { beets }\end{array}$ \\
\hline Sugar beet $\ldots \ldots$ & $\begin{array}{l}\text { Kuhn P } \\
\text { Kleinwanzleben E }\end{array}$ & $\begin{array}{l}\text { SX } \\
\text { SY }\end{array}$ & $\begin{array}{l}75 \\
82\end{array}$ \\
\hline $\begin{array}{l}\text { Fodder beet of very high dry matter } \\
\text { content }\end{array}$ & Friso & VA & 102 \\
\hline Fodder beet of high dry matter content & Alpha & VC & 112 \\
\hline Fodder beet of low dry matter content & $\begin{array}{l}\text { Barres Strynø X } \\
\text { Peragis }\end{array}$ & $\begin{array}{l}\text { VD } \\
\text { VE }\end{array}$ & $\begin{array}{l}111 \\
107\end{array}$ \\
\hline
\end{tabular}

The percentage of beets producing seed was small. On account of the work involved in the cytological examination it was aimed to harvest seed of some 100 tetraploid individuals per variety and this was successfully carried out. It should be ascertained whether this guaranteed sufficient possibilities for the breeding of tetraploids.

\section{$C_{1}$ generation}

The $\mathrm{C}_{1}$ seed was sown in a glasshouse in the autumn; the tetraploids were selected after cytological examination in the four-leaf stage or on root-tips (fig. 1). An attempt was made to get at least $3 C_{1}$ beet plants from every $C_{0}$ mother beet, but this was not always possible. In the material treated with colchicine in 1950, seed was harvested in 
1951 also from stems which had not been examined cytologically. The result was that the percentage tetraploids in the $\mathrm{C}_{1}$ was about $60 \%$. Among these there were mother beet plants which did not yield a single tetraploid on 10 and more offspring.

The next year, when only seed was harvested from cytologically checked stems, this occurred to a far lesser degree; now the percentage of tetraploids amounted to $\pm 85 \%$. An accurate examination of the $C_{0}$ generation has the advantage that in the $C_{1}$ a far smaller number of beet may be examined to select an equal number of tetraploids.

According to the procedure described above it is possible to restrict the cytological examination of the $C_{1}$ to a minimum. By vernalisation in the course of the winter the vegetative period of the plant was reduced to ten months so that already in the course of the following summer seed could be harvested.

\section{$C_{2}$ generation}

The $C_{2}$ seed was sown in a trial in order to obtain an impression of the characters displayed. The $C_{2}$ offspring of the same mother beets $\left(C_{0}\right)$ were laid out in adjoining plots in order to facilitate comparison. In order to prevent degeneration by inbreeding as much as possible, the polycross method was used.

In assessing the value, special attention was paid to root weight, dry matter content (of all varieties) and the sugar content of the sugar beet varieties. On the basis of the results obtained the best families were separated from those which were less promising. The next year they were also propagated by separate isolation. This was possible because a reserve field had been laid out with all the families (fig. 2). One row was taken from each family, which was sufficient for a good comparison of leaf type. From the best families 10 roots were chosen (by sight) for seed production, while of the other families 3 roots were destined for seed production (fig. 3) with a view to maintenance.

In polyploidy breeding tetraploid forms are obtained which are physiologically different from the diploids in every respect. It has appeared that in the course of the first few generations after colchicine treatment a stabilization of the material takes place. During this process it becomes cytologically and physiologically adapted to the environment. This causes less valuable types to be eliminated which means that families that at first do not look very promising, later can make a better impression (RASMUSSON, 11). Therefore it is recommended not to select too strictly for yield in the first few generations so that the less promising types are given an opportunity to adapt themselves.

\section{$C_{3}$ generation}

Seed of the best families was sown on a trial field in order to compare them with the initial material and to ascertain the effects of selection.

The $\mathrm{C}_{3}$ seed harvested from the remaining families was sown on the trial field as a mixture in order to gain an impression of the production capacity.

The building up of the tetraploid varieties is now completed. A number of good families has been chosen to ascertain the behaviour and purity of the tetraploids in later generations and to study the possibilities of using them for several purposes. In publications to follow the results of intercrossing the tetraploids will be given and also the production of triploids. 


\section{RESULTS OBTAINED}

In 1953 and following years families of the sugar beet varieties were tested on the trial field (figs 4a and 4b). The fodder beet varieties were tested in the years 1954, 1955, 1956 and 1957. The results obtained have been included in tables 2 and 3 .

TABle 2. Comparison OF TETRAPLOID AND Diploid famiLies

\begin{tabular}{|c|c|c|c|}
\hline Year & Variety & $\begin{array}{l}\text { Number of } \\
\text { tetraploid families }\end{array}$ & $\begin{array}{l}\text { Number of families better } \\
\text { than the diploid varieties }\end{array}$ \\
\hline 1953 & SX and SY & 44 & 18 \\
\hline 1954 & SXand $S Y ; V A, V B, V C$ and VD & 269 & 52 \\
\hline 1955 & SX andSY;VA,VB, VC and VE & 131 & 37 \\
\hline 1956 & SXand SY;VA, VB, VC and VD & 241 & 116 \\
\hline 1957 & SX and SY; VA, VB, and VE . & 108 & 27 \\
\hline
\end{tabular}

TABLE 3. COMPARISON OF TETRAPLOID FaMILIES AND THE DIPLOID VARIETIES FROM WHICH THEY WERE DERIVED

\begin{tabular}{c|c|c}
\hline Variety & Number of families & $\begin{array}{c}\text { Number of families better than } \\
\text { the diploid varieties }\end{array}$ \\
\hline SX & 127 & 31 \\
SY & 116 & 46 \\
VA & 117 & 67 \\
VB & 156 & 37 \\
VC & 93 & 39 \\
VD & 90 & 27 \\
VE & 94 & 3 \\
Total & 793 & $250( \pm 32 \%)$
\end{tabular}

From the tables 1, 2 and 3 it follows that the number of $\mathrm{C}_{0}$ families from which seed was harvested is smaller than the number which was sown on the trial field. This is due to the fact that of several families more components were sown out on the field. When sufficient seed of separate $C_{1}$ plants was obtained it was sown on the trial field. In table 2 the total number of families has been included.

Table 3 includes the number of families derived from $\mathrm{C}_{0}$ beets and shows that a reasonable percentage ( $32 \%$ ) has given favourable results. The families have been compared with commercial varieties of which the seed was harvested in the previous year. In this connection it should be mentioned that breeders are continuously trying to improve their varieties and in general they will now be better than they were in 1950,1951 and 1952, when the seed was treated with colchicine.

The variety VE is, relatively taken, the worst of all because of the occurrence of a high percentage of bolters. This is partly due to the fact that in 1953 the harvested seed had to be stored in a moist place. In later years the number of bolters was much lower.

Further it should be borne in mind that since 1950 much work has been done to improve the variety Peragis (personal communication). It could therefore be expected 


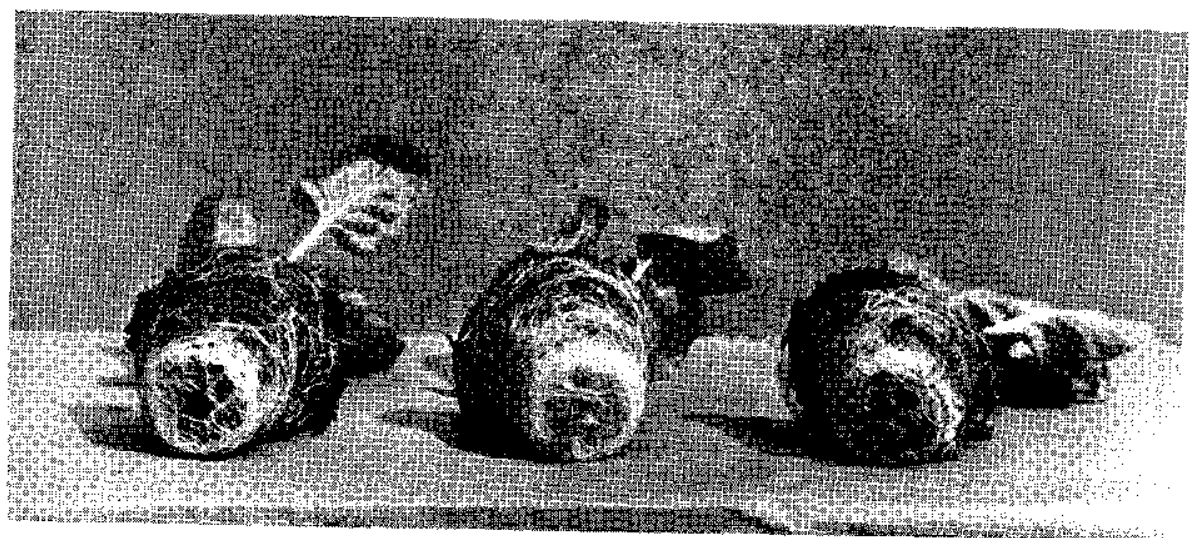

Fici. l. Ci PI.ANTS CiROWN IN POTS FOR CYTOLOGICAL INVESTIGIATION

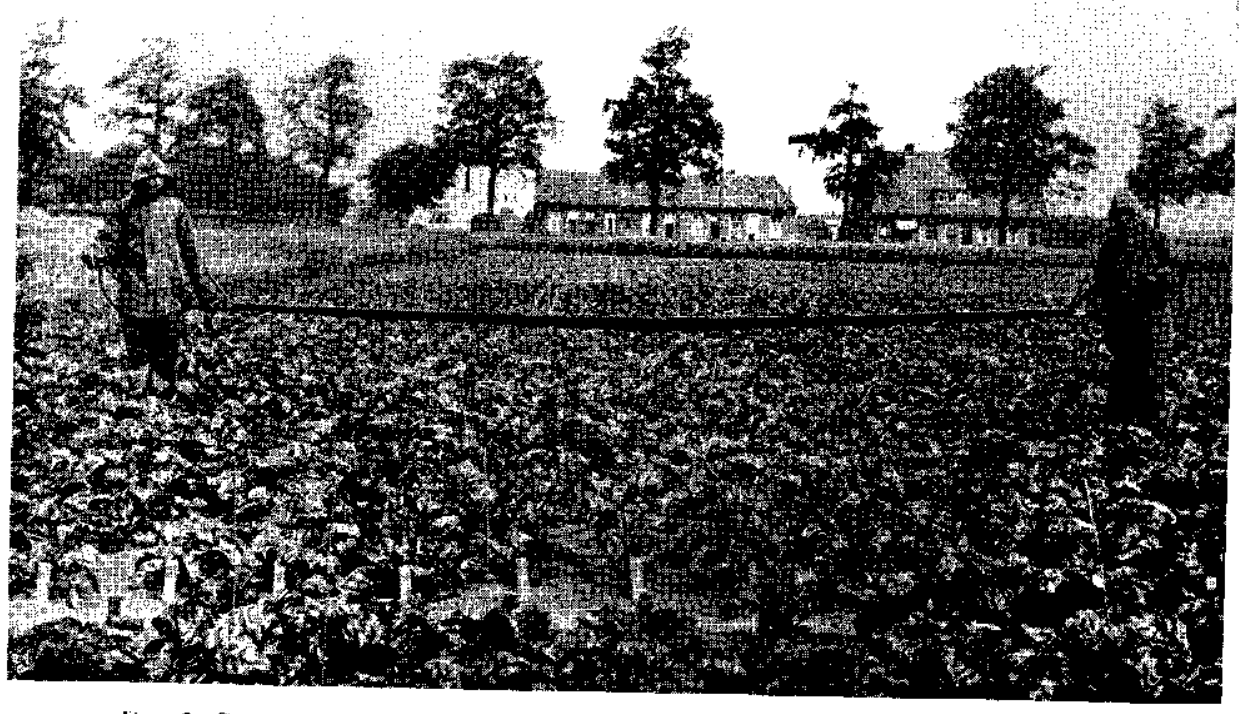

FIK. 2. SURVHY OF THE RESERVE HIELD SPRAYED WITH METASYSTOX AGANASY APHIDS 
D. KLOEN AND G. J. SPECKMANN

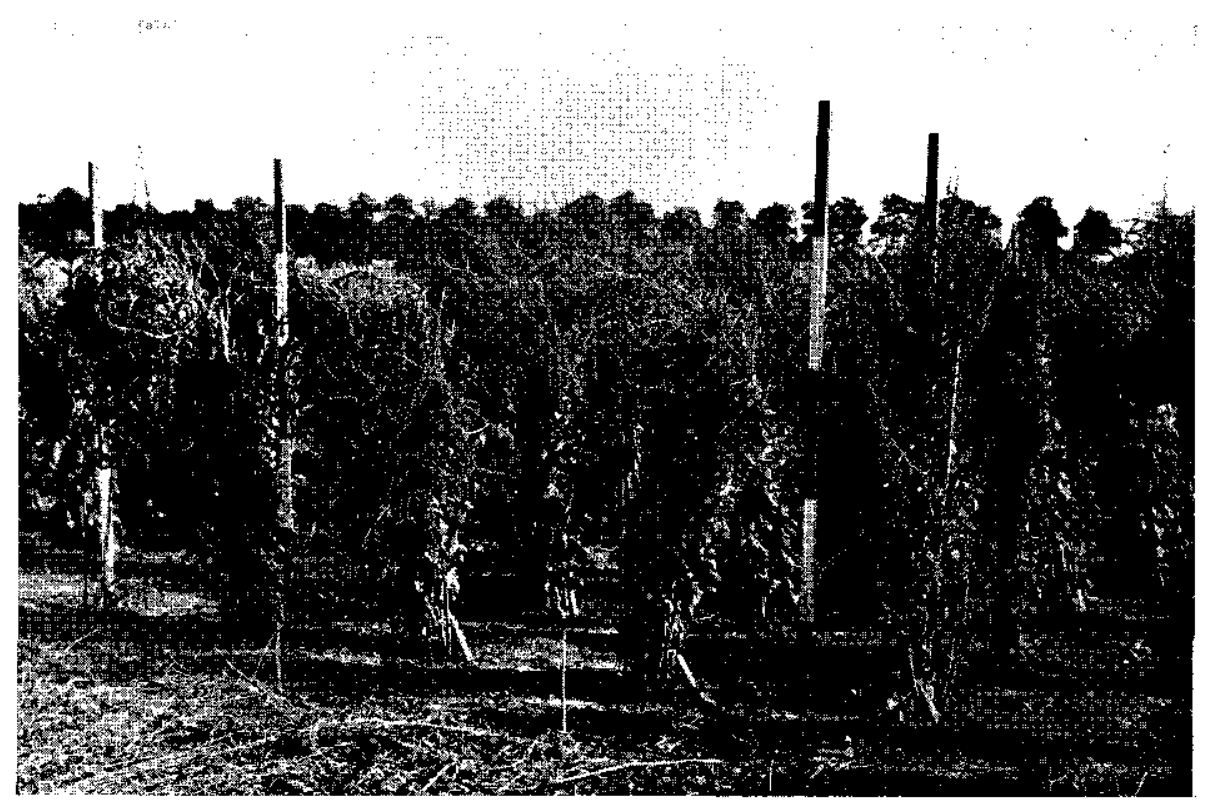

Fig. 3. SEED PRODUCTION OF TETRAPLOID FaMILIES 


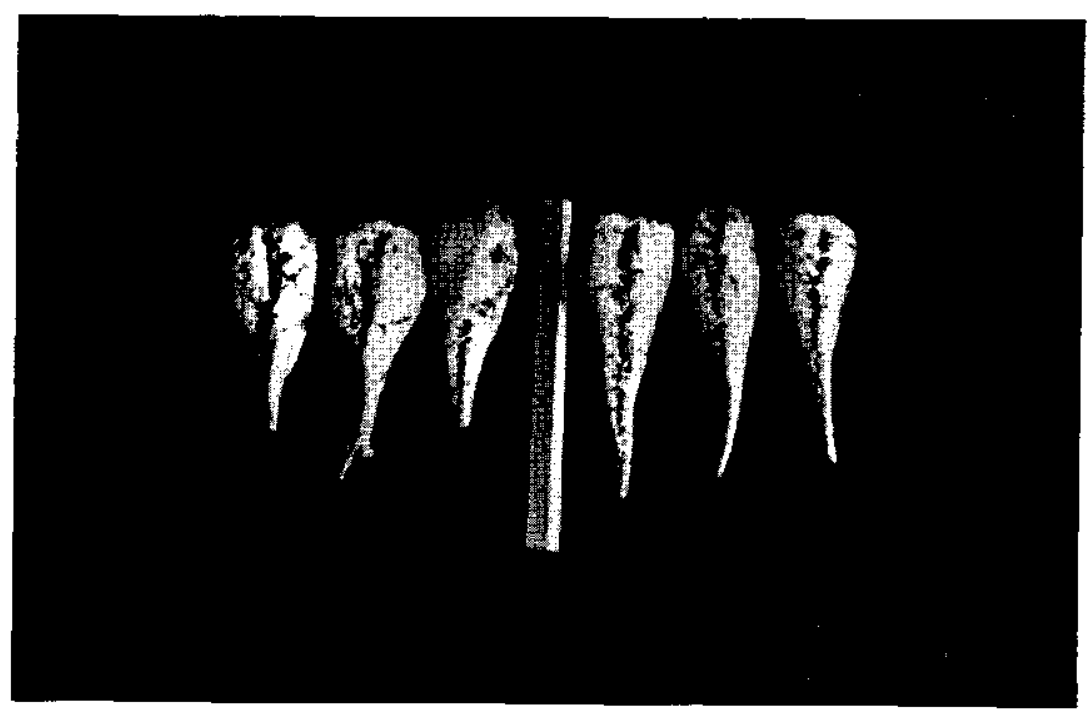

FIG. 4a. BEETS OF AN SY FAMILY

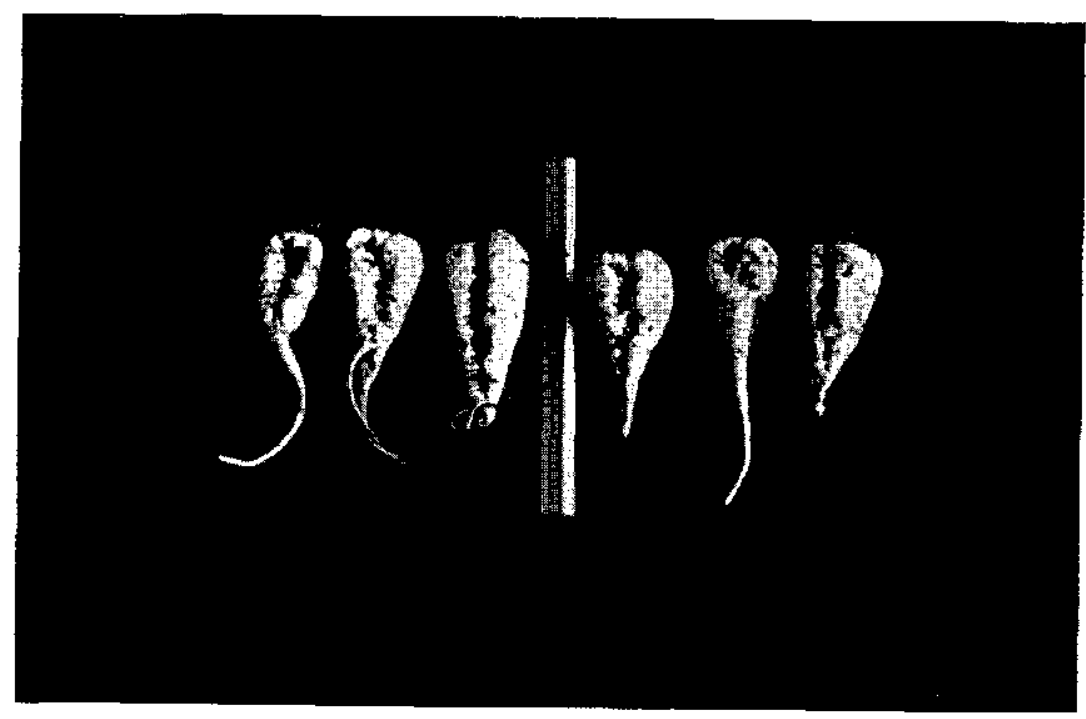

Fici. 4h. BHFts OF THF, VARIITY KLLinWANZI.FBEN FRom Which SY IS DFRIVII) 
that a comparison with tetraploid material from commercial seed of some years ago would make a less favourable impression for this variety.

As was already mentioned, seed of the best tetraploid families derived from one year was sown (in the case of sugar beet varieties of two years). The following table gives the dry matter and sugar content as well as the dry matter and sugar yield, in order to give an impression of the variation in these characteristics. The seed was sown in six replications of $8 \mathrm{~m}^{2}$ (60 plants) in 1956.

TABle 4. The SUgar CONTENT AND SUgar YiEld OF THE TETRAPLOID FAMILIES

\begin{tabular}{|c|c|c|c|c|c|c|c|c|c|c|}
\hline \multicolumn{2}{|c|}{$\begin{array}{l}\text { No. } \\
\text { SX }\end{array}$} & $\begin{array}{l}\text { Sugar } \\
\text { content }\end{array}$ & $\begin{array}{c}\text { Sugar yield } \\
\mathrm{kg} / \text { plot }\end{array}$ & \multicolumn{5}{|c|}{$\begin{array}{l}\text { No. } \\
\text { SY }\end{array}$} & $\begin{array}{c}\text { Sugar } \\
\text { content }\end{array}$ & $\begin{array}{c}\text { Sugar yield } \\
\mathrm{kg} / \text { plot }\end{array}$ \\
\hline 47 & . . & 16.63 & 8.69 & $1441 .$. & . . & . . & . & . & 15.49 & 8.13 \\
\hline 108 & . . & 17.98 & 7.55 & $1037 .$. & . . & . . & . & . & 15.60 & 8.07 \\
\hline 1005 & . . & 17.03 & 7.36 & 420 . . & . . & . . & . & . & 16.33 & 7.91 \\
\hline 1002 & . & 17.55 & 7.30 & 1034. & . . & . . & . & . & 15.82 & 7.86 \\
\hline 1023 & . . & 17.13 & 7.25 & $1007 .$. & . . & . . & . & . & 16.12 & 7.79 \\
\hline 118 & . & 16.62 & 7.18 & $498 \ldots$. &. & . & . & . & 16.20 & 7.77 \\
\hline 99 & . . & 17.63 & 7.14 & $1039 .$. & . . & . . & . & . & 15.40 & 7.77 \\
\hline 1012 & . & 17.23 & 7.08 & 1040. & . . & . . & . & . & 14.75 & 7.75 \\
\hline 1025 & . & 16.75 & 7.03 & 1042 & . & . . & . & • & 15.82 & 7.73 \\
\hline 1016 & . . & 17.43 & 6.99 & $1030 .$. & . & . . & . & . & 15.85 & 7.70 \\
\hline 127 & . . & 17.14 & 6.93 & 1033. & . & . . & . & - & 16.08 & 7.65 \\
\hline 1020 & . . & 17.25 & 6.81 & 1032 . . & $\cdot$ & . . & . & - & 16.10 & 7.64 \\
\hline & & & & $1169 .$. & . . & . . & . & . & 16.17 & 7.57 \\
\hline & & & & $1028 .$. & . & . . & • & & 16.00 & 7.57 \\
\hline & & & & 416. & . & . & . & & 16.15 & 7.49 \\
\hline & & & & 487. & · · & . . & . & & 14.35 & 6.95 \\
\hline Kuhn & P. & 17.20 & 7.11 & Kleinwanz & zleb & en $\mathrm{I}$ & E. & & 16.60 & 7.14 \\
\hline
\end{tabular}

The sugar content of SX compared with Kuhn $\mathbf{P}$ is more prominent than that of SY compared with Kleinwanzleben $E$. There is a considerable variation in content and weight, and this offers good prospects for selection. (Table 4.)

The dry matter content of VA approaches that of Friso more closely than that of VB when compared with fodder sugar beet $C B$ which is somewhat better. This is also apparent when the varieties VA and VB are compared with one another. (Table 5.)

The dry matter content of VC and VD does not differ much from the original varieties but in this case there are valuable families as concerns dry matter weight. The variety VE cannot yet be included in this survey. (Table 6.)

From the tables ( 7 and 8 ) it is clear that the families make a favourable impression. Only the order of dry matter yield has undergone some change.

A seed mixture was also composed of the best families SX and SY. The results are given in table 8 . 


\section{KLOEN AND G. J. SPECKMANN}

TABLE 5. FODDER BEET OF HIGH DRY MATTER CONTENT

\begin{tabular}{|c|c|c|c|c|c|}
\hline $\begin{array}{l}\text { No. } \\
\text { VA }\end{array}$ & $\begin{array}{l}\text { Dry matter } \\
\text { content }\end{array}$ & $\begin{array}{l}\text { Dry matter } \\
\text { yield } \mathrm{kg} / \text { plot }\end{array}$ & $\begin{array}{l}\text { No. } \\
\text { VB }\end{array}$ & $\begin{array}{l}\text { Dry matter } \\
\text { content }\end{array}$ & $\begin{array}{l}\text { Dry matter } \\
\text { yield } \mathrm{kg} / \mathrm{plot}\end{array}$ \\
\hline 1068 & 21.33 & 9.96 & $1165 \ldots$ & 19.11 & 10.88 \\
\hline 1047 & 21.64 & 9.61 & $1149 \ldots \ldots$ & 19.16 & 10.42 \\
\hline 1049 & 21.68 & 9.46 & 1158. & 19.88 & 10.25 \\
\hline 1046 & 22.18 & 9.33 & 1140. & 18.85 & 10.07 \\
\hline 1098 & 21.87 & 9.31 & . . . . & 19.72 & 9.94 \\
\hline 1105 & 21.77 & 9.22 & ... & 19.52 & 9.91 \\
\hline 1092 & 21.50 & 9.20 & 1156. & 19.81 & 9.84 \\
\hline 1063 & 21.64 & 9.12 & 1181. & 19.44 & 9.76 \\
\hline 1099 & 21.29 & 9.01 & 1185. & 19.39 & 9.71 \\
\hline 1080 & 21.43 & 8.99 & . . . & 19.07 & 9.52 \\
\hline 1060 & 21.34 & 8.96 & $1118 \ldots \ldots$ & 19.43 & 9.20 \\
\hline 1069 & 20.81 & 8.85 & & & \\
\hline 1070 & 21.58 & 8.83 & & & \\
\hline Friso. & 21.57 & 9.46 & Fodder sugar beet $\mathrm{CB}$ & 19.98 & 9.76 \\
\hline
\end{tabular}

TABLE 6. FODDER BEET OF MFDIUM AND LOW DRY MATTER CONTENT

\begin{tabular}{|c|c|c|c|c|c|}
\hline $\begin{array}{l}\text { No. } \\
\text { VC }\end{array}$ & $\begin{array}{c}\text { Dry matter } \\
\text { content }\end{array}$ & $\begin{array}{l}\text { Dry matter } \\
\text { yield } \mathrm{kg} / \mathrm{plot}\end{array}$ & $\begin{array}{l}\text { No. } \\
\text { VD }\end{array}$ & $\begin{array}{l}\text { Dry matter } \\
\text { content }\end{array}$ & $\begin{array}{l}\text { Dry matter } \\
\text { yield } \mathrm{kg} / \text { plot }\end{array}$ \\
\hline 1235 & 16.35 & 10.53 & $1280 \ldots \ldots$ & 11.79 & 9.48 \\
\hline 1234 & 16.42 & 10.23 & $1263 \ldots \ldots$ & 12.17 & 9.41 \\
\hline 1230 & 16.13 & 9.97 & 1264. & 12.26 & 9.39 \\
\hline 1196 & 16.82 & 9.96 & 1255 & 11.87 & 9.31 \\
\hline 1210 & 16.39 & 9.80 & 1277. & 12.03 & 9.07 \\
\hline 1227 & 16.53 & 9.72 & $1272 \ldots$ & 12.31 & 9.06 \\
\hline 1211 . & 16.64 & 9.54 & . . . . . & 11.90 & 9.06 \\
\hline $1214 \ldots$ & 16.42 & 9.48 & .... & 11.93 & 9.05 \\
\hline $1237 \ldots$ & 15.92 & 9.35 & 1240. & 11.84 & 9.03 \\
\hline 1216 & 16.23 & 9.26 & 1280 & 11.55 & 8.92 \\
\hline 1229 & 16.47 & 9.24 & $1282 \ldots$ & 12.11 & 8.91 \\
\hline \multirow[t]{5}{*}{1192} & 16.22 & 9.15 & 1243 & 11.78 & 8.81 \\
\hline & & & 1269. & 12.18 & 8.79 \\
\hline & & & $1258 \ldots$ & 12.14 & 8.55 \\
\hline & & & $1257 \ldots$ & 12.28 & 8.06 \\
\hline & & & $1247 \ldots . .$. & 12.28 & 8.06 \\
\hline Alpha. & 16.36 & 9.56 & Barres Strynø X . . . & 12.08 & 8.85 \\
\hline
\end{tabular}

TABLE 7. Results OF SELECTION IN TWO CONSECUTIVE GENERATIONS

\begin{tabular}{c|c|c|c}
\hline \multirow{2}{*}{ Variety } & \multicolumn{2}{|c|}{ Selection in the $\mathrm{C}_{2}$ stage } & $\begin{array}{c}\text { Examination in the } \mathrm{C}_{3} \text { stage } \\
\text { Better than or equal to } \\
\text { original variety }\end{array}$ \\
\cline { 2 - 4 } Su & $\begin{array}{c}\text { Number of best } \\
\text { families }\end{array}$ & $\begin{array}{c}\text { Better than or equal to } \\
\text { original variety }\end{array}$ & 7 \\
SY & 14 & 14 & 7 \\
VA & 16 & 1 & 3 \\
VB & 13 & 4 & 8 \\
VC & 14 & 6 & 6 \\
VD & 12 & 10 & 11
\end{tabular}


TABLE 8. RESUlt OF SEED MiXTURES OF BEST FAMILIES

\begin{tabular}{c|c|c}
\hline & Sugar content & Sugar yield kg/plot \\
\hline SX & 17.07 & 7.13 \\
SY & 15.83 & 7.56
\end{tabular}

On comparison with the original material (table 4) SX has a good sugar content; SY has a good sugar yield, but the sugar content is not satisfactory.

As was already mentioned, seed was also harvested from the other families of which two yearly harvests flowered simultaneously. In 1956 seed was collected of the families isolated in 1954 and 1955 and this was sown in a trial as a mixture in 1957 (table 9).

TABLE 9. COMPARISON OF THE BEST FODDER BeET FAMILIES WITH THE OTHER FAMILIES

\begin{tabular}{l|c|c|c|c}
\hline & \multicolumn{2}{|c|}{ Dry matter content } & \multicolumn{2}{c}{ Dry matter yield $\mathrm{kg} / \mathrm{plot}$} \\
\cline { 2 - 5 } & Best families & Other families & Best families & Other families \\
\hline VA & & & & \\
1955 & 20.2 & 20.0 & 10.94 & 10.75 \\
1956 & 19.2 & 20.4 & 11.14 & 11.06 \\
VB & & & & \\
1955 & 19.1 & 19.4 & 11.24 & 10.30 \\
1956 & 19.0 & 19.8 & 10.82 & 10.20 \\
VC & & & & \\
1955 & 15.5 & 15.2 & 11.38 & 11.07 \\
1956 & 15.6 & 15.5 & 11.13 & 11.08
\end{tabular}

It is apparent that there is only little difference in the contents compared. In connection with the dry matter content it should be stated that a seed mixture does not present an equally reliable picture as the average of the families. For technical reasons it was not possible to carry this out in the most reliable way. In the variety VC the gain in yield by the selection was not great and this also holds for the variety VA. From this the conclusion may be drawn that the other families have given a better impression in the following generation on account of the stabilization mentioned above. The variety VB showed a clear difference and in this variety the best families produced better figures than those of the other two families when compared with the diploid fodder sugar beet $\mathrm{CB}$.

The results from the tetraploid families of 2 sugar beet and 5 fodder beet families show that in the $\mathrm{C}_{2}$ stage a larger number of families were better than the diploid varieties from which they had been derived. It follows that breeding for tetraploidy offers better prospects than was assumed at first. If the observations and suggestions of RASMUSSON are correct the material will undoubtedly improve still further according to the adaptation of the material to the environment.

From the investigations described in this paper the conclusion may be drawn, in addition to KNAPP's (7) opinion, that tetraploidy-breeding in beet offers more possibilities than was hitherto assumed, provided that the breeding-programme is set up on a sufficiently broad basis at the outset. 


\section{SamenVATting}

\section{Het opbrengstvermogen van tetraploide suiker- en voederbieten}

Sedert de ontdekking van de toepassingsmogelijkheden van colchicine in de plantenveredeling zijn de kwekers begonnen met het tetraploid maken van suiker- en voederbieten. De verkregen resultaten waren niet erg hoopvol en reeds spoedig is men daarom overgegaan tot het creëren van rassen, waarin triploiden voorkomen.

De S.V.P. is in 1950 begonnen met de polyploidieveredeling van 2 suikerbieten en 5 voederbietenrassen. Door de afwijkende bieten in hun eerste en tweede levensjaar nauwkeurig cytologisch te onderzoeken werd zaad verkregen, waarin een hoog percentage tetraploiden voorkwam. In een éénjarige zaadteelt werd van de $C_{1}$ bietenzaad geoogst, dat op het proefveld werd uitgezaaid.

In totaal werden 798 families in het $\mathrm{C}_{2}$ stadium onderzocht en hiervan bleek $32 \%$ beter te zijn dan de diploide uitgangsrassen. Van een jaargang werd van de beste families zaad op het proefveld uitgezaaid, het percentage van het aantal families, dat beter was dan het uitgangsmateriaal bleek iets groter.

Van de overige families werd ook zaad geoogst; zij kwamen in het stadium $\mathrm{C}_{3}$ iets slechter naar voren dan de beste families.

Aan de daarvoor in aanmerking komende kwekers zijn van alle families in het $\mathrm{C}_{1}$-, $\mathrm{C}_{2}$ - of $\mathrm{C}_{3}$-stadium zaad en stekbieten afgestaan, waarmede de opbouw van de tetraploide rassen door de S.V.P. is afgesloten.

\section{REFERENCES}

1. AbEGG, F. A., The induction of polyploidy in Beta vulgaris L. by colchicine treatment. Proc. Amer. Soc. Sugar Beet Technologists (Second General Meeting) (1940): 118-119.

2. AbegG, F. A., Stewart, D. and Coons, G. H., Further studies on sugar-beet autotetraploids. Proc. Amer. Soc. Sugar Beet Technologists (Fourth Gen. Meeting) (1946): 223-229.

3. Armstrong, J. M., Production and value of polyploid field roots. Scientific Agriculture 22 (1942): 787-798.

4. ERnould, L., .l'Autopolyploidie expérimentale chez la betterave. Publications de l'Institute Belge pour l'Amélioration de la Betterave 14 (1946): 205-269.

5. Frandsen, K. J., Colchicininduzierte Polyploidie bei Beta vulgaris L. Der Züchter 11 (1939): 17-19.

6. Kloen, D. and Speckmann, G. J., The creation of tetraploid beets. Euphytica 2 (1953): 187-196; 3 (1954): 35-42; 154-160; 5 (1956): 308-322; 6 (1957): 193-197.

7. KNAPP, E., The significance of polyploidy in sugar beet breeding. Proceedings of the International Genetics Symposia, Tokyo 1956: 300-304.

8. Peto, F. H. and BoYes, J. W., Comparison of diploid and tripleid sugar beets. Can. J. Research C, 18 (1940): 273-282.

9. Peto, F. H. and HILL, K. W., Colchicine treatments of sugar beets and the yielding capacity of the resulting polyploids. Proc. Amer. Soc. Sugar Beet Technologists (Third Gen. Meeting-1942) (1943): 287-295.

10. Polyploidie der Rüben. Beiträge zur Rübenforschung. No. 1. Wissenschaftliche Abhandlungen, Akademie-Verlag, Berlin. No. 34, (1958): 68 pp.

11. Rasmusson, J., Autotetraploid sugar beets. Vitality changes in subsequent generations. Hereditas 39 (1953): 257-269.

12. SCHLOSSER, L. A., Untersuchungen an autopolyploiden Zuckerrüben. I.Z. Wirtschaftsgr. Zuckerindustrie 90 (1940): 88-106.

13. Stewart, S., and Gaskill, J. O., Results of field tests with triploid sugar beets in 1951. Proc. Amer. Soc. Sugar Beet Technologists (Seventh Gen. Meeting) (1952): 452-453. 


\section{Mededelingen van de Stichting voor Plantenveredeling Publications of the Foundation for Agricultural Plant Breeding \\ Nude 66, Wageningen, Netherlands}

No. 1. LAMBERTs, H., Verbreding van de grondslagen voor de veredeling van de gele voederlupine. (Broadening the bases for the breeding of yellow sweet lupine.). 1955. Prijs $f$ 1,00. (Dissertatie).

No. 2. WIT, F., MARGadanT, W. D. en Dilz, K. Jarowisatie bij Engels en Italiaans raaigras (Lolium perenne en L. multiflorum). (Vernalization in perennial and Italian ryegrass). Landbouwkundig Tijdschrift 2 (1955): 137-147. Prijs f 0,25. Uitverkocht.

No. 3. Disk, G. E. vaN, The influence of sward-age and management on the type of timothy and cocksfoot (De invloed van ouderdom en de gebruikswijze op timothee en kropaar in Nederlandse grasslanden). Euphytica 4 (1955): 83-93. Prijs f 0,25. Uitverkocht.

No. 4. Huissman, C. A., Breeding for resistance to the potato root eelworm II (Het kweken op resistentie tegen het aardappel-cystenaaltje II). Euphytica 4 (1955): 133-140. Prijs $f$ 0,25. Uitverk. No. 5. SpECKMANN, G. J., A rapid laboratory method for cytological control in polyploidy breeding (Een snelle methode voor cytologische controle bij polyploïdie-veredeling). Euphytica 4 (1955): 163-166. Prijs f 0,25. Uitverkocht.

No. 6. Wiersema, H. T., Flax scorch (Vlasbrand). Euphytica 4 (1955): 197-205. Prijs f 0,25. Uitverk. No. 7. WIT, F. and SPECKMANN, G. J., Tetraploid Westerwolths Ryegrass (Tetraploid Westerwolds raaigras) Euphytica 4 (1955): 245-253. Prijs f 0,25. Uitverkocht.

No. 8. THIJN, G. A., Methods used in evaluating potato seedlings. (De verdere opkweek van aardappelzaailingen). Euphytica 5 (1956): 55-62. Prijs f 0,25.

No. 9. Huisman, C. A., Breeding for resistance to the potato root eelworm in the Netherlands. Nematologica 1 (1956): 94-99. Prijs f 0,25. Uitverkocht.

No. 10. Wrr, F., A possible virus disease in Lolium perenne. (Een virusziekte in Engels raaigras) Euphytica 5(1956): 119-129. Prijs f 0,25. Uitverkocht.

No. 11. Diskruis, G. J., Computation of heat unit accumulations in maize for practical application. (Berekening van warmtesommen voor praktische toepassing bij maïs). Euphytica 5 (1956): 267-275. Prijs $f 0,25$.

No. 12. DijKstra, J., Experiences with the breeding of red clover resistant to the stem eelworm. (Enige ervaringen met het kweken van rode klaver die resistent is tegen het stengelaaltje) Euphytica 5 (1956): 298-307. Prijs f 0,25.

No. 13. Kloen, D. and Speckmann, G. J., The creation of tetraploid beets. IV. Morphological and physiological characteristics of $\mathrm{C}_{2}$ beets. (Het verkrijgen van tetraploide bieten. IV morfologische en fysilogische eigenschappen van $C_{2}$ bieten) Euphytica 5 (1956): 308-322. Prijs f 0,25.

No. 14. Huissman, C. A., Veredeling van de aardappel op resistentie tegen Heterodera rostochiensis Wollenweber (Breeding for resistance to the potato root-eelworm Heterodera rostochiensis W.), 1957. Prijs f 1,25 (Dissertatie).

No. 15. Kloen, D. and Speckmann, G. J., The creation of tetraploid beets. V. Cytological investigations on $C_{2}$ beets. (Het verkrijgen van tetraploide bieten. V. Cytologische controle van $C_{2}$ bieten). Euphytica 6(1957): 193-197. Prijs f 0,25.

No. 16. DiJkstra, J., Symptoms of susceptibility and resistance in seedlings of red clover attacked by the stem eelworm Ditylenchis dipsaci (Kühn) Filipjev. Nematologica 2 (1957): 228-237. Prijs f 0,25 .

No. 17. HuIJSMan, C. A., Resistance to the potato root ealworm in $S$. tuberosum subsp. andigena and its importance for potato bresding. Neth. Journ. of Agric. Sc. Vol. 6. No. 1 (1958): 39-46. Prijs $\mathrm{f} 0,25$.

No. 18. Dantuma, G., Veredeling van tarwe en gerst op winterhardheid (Breeding wheat and barley for winterhardiness), 1958. Prijs f 1,25 (Dissertatie).

No. 19. WIT, F., Tetraploid Italian ryegrass (Lolium multiflorum Lam.). (Tetraploid Italiaans raaigras) Euphytica 7 (1958): 47-58. Prijs f 0,25.

No. 20. De eerste tien jaren. (The first ten years). 1958. Prijs $f \mathbf{2 , 5 0 .}$

No. 21. WIT, F., Hybrids of ryegrasses and meadow fescue and their value for grass breeding (Bastaarden van raaigrassen en beemdlangbloem $\mathrm{en}$ hun betekenis voor de grassenveredeling). Euphytica 8 (1959): $1-12$. Prijs f 0,25 .

No. 22. Kloen, D. and Speckmann, G. J., The yiziding capacity of tetraploid sugar and fodder beets. (Het opbrengstvermogen van tetraploide suiker- en voederbieten.) Euphytica 8 (1959): 29-36. Prijs $f 0,25$. 
LAMBERTS, H., Some remarks on sweet lupine. Farming 2 (1948): 90-91.

LAMBerts, H., De teelt, de veredeling en de zaaizaadvoorziening van de voederlupine. Landbouwk. Tijdschr. 60 (1948): 413-421.

LAMBERTS, H., Enting van gele voederlupine. Landbouwk. Tijdschr. 63 (1951): 187-188.

LAMBerTs, H., Resistentie tegen aantasting door Fusarium oxysporum in gele lupine. Landbouwk. Tijdschr. 63 (1951): 458-459.

Thrs,, G. A., De afstamming en de nakomelingen van de Katahdin aardappel. Euphytica 1 (1952): $57-59$.

ThIJN, G. A., Potato varieties and powdery mildew attacks. Euphytica 1 (1952): 84-86.

WrT, F., The pollination of perennial ryegrass (Lolium perenne L.) in clonal plantations and polycross fields. Euphytica 1 (1952) 95-104.

LAMBERTS, H., Resistance to mildew in yellow lupine. Euphy tica 1 (1952): 199-200.

WIT, F., Techniques of breeding cold-resistant grasses and clovers. Proc. of the Sixth Intern. Grassland Congr. 2 (1952): 1607-1612.

LAmberts, H. en Tolner, J., Gele voederlupine. Teelt, gebruik en veredeling van een voedergewas. Uitgeverij Ceres. Meppel 1952, 115 pp.

LAMBERTS, H., A new type with a rapid youth growth in yellow lupine. (Lupinus luteus). Euphytica 2 (1953): 59-61.

WIT, F., Veredelingsaspecten van het zesde internationale grasland congres. Euphytica 2 (1953): $72-75$.

SiEBEN, J. W., The correlation between resistance to lodging and fibre content in flax. Euphytica 2 (1953): 101-106.

KORSTEN, L. H. J. e.a., A colorimetric determination of the number of eelworms in a suspension. A new technic to be used in connection with the breeding of resistant clovers. Euphytica 2 (1953): $135-138$.

Toxopeus, H. J. and HuIJSMan, C. A., Breeding for resistance to potato root eelworm. 1. Preliminary data concerning the inheritance and the nature of resistance. Euphytica 2 (1953): 180-186.

KloEn, D. and SpeckmanN, G. J., The creation of tetraploid beets. I. Euphytica 2 (1953): 187-196.

KorSTEN, L. H. J., Een nieuwe methode voor bepaling van de vatbaarheid van klaverplanten voor het stengelaaltje (Ditylenchus dipsaci (Kuhn) Filipjev). Tijdschr. over Plantenziekten 59 (1953): 27-28.

ThiJ, G. A., Observations on flower induction with potatoes. Euphytica 3 (1954): 28-34.

Kloen, D. and SpeckmanN, G. J., The creation of tetraploid beets. II. Selection in the first generation (the $C_{1}$ ) from the treated material. Euphytica 3 (1954): 35-42.

SIEBEN, J. W., Het gebruik van nomogrammen ter vereenvoudiging van berekeningen. Euphytica 3 (1954): 64-67.

Thun, G. A., The raising of first year potato seedlings in glasshouses. Euphytica 3 (1954): 140-146.

Kloen, D. and SpeckmanN, G. J., The creation of tetraploid beets. III Cytological checking in the second generation (the $C_{2}$ ) of the treated material. Euphytica 3 (1954): 154-160.

Dantuma, G., Daglengte-onderzoek bij tarwe en gerst. CoCoBro-Jaarboekje 4 (1954): $62-69$.

KLOEN, D., Vernalization as a means of accelerating production of seed. Annexe 1954-1 au Bulletin de l'Institut International du Froid, Paris, 6 pp.

WIT, F. and SPECKMANN, G. J., Breeding of tetraploid ryegrasses. European Grassland Conf. organized by the Min. of Agric. for France with the co-operation of the European Productivity Agency of the Organization for European Economic Co-operation. Held in Paris 21-24 Juni 1954. Stencil $10 \mathrm{pp}$.

WIT, F., De perspectieven van chromosomenverdubbeling voor de veredeling van raaigrassen en rode klaver. Landbouwk. Tijdschr. 66 (1954): 533-536. 